\section{Godt om nevropsykiatri}

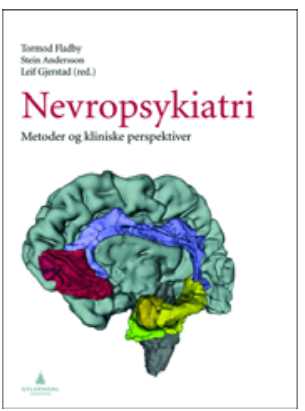

Tormod Fladby, Stein Andersson,

Leif Gjerstad, red.

Nevropsykiatri

Metoder og kliniske perspektiver. 228 s, tab,

ill. Oslo: Gyldendal Akademisk, 2012.

Pris NOK 425

ISBN 978-82-05-41214-9

Nyere kunnskap om sammenhengen mellom kropp, sinn og hjerne aktualiserer fagområdet nevropsykiatri på en ny måte. Det er ikke lenger like aktuelt å snakke om skillet mellom såkalt funksjonelle og organiske lidelser. Kronisk stress og traumatiske livshendelser påvirker hjernen og kan gi grunnlag for både somatiske og psykiatriske lidelser. Vi vet også at hjernen har en langt større plastisitet enn tidligere antatt. Fagområdet nevropsykiatri er derfor svært sentralt for både forståelse og behandling av psykiske lidelser, og det er derfor gledelig at vi har fått en ny, norsk lærebok i emnet.

Målgruppen er primært leger, psykologer og studenter innenfor disse områdene, men boken kan også være nyttig for andre helseprofesjoner innen psykisk helsevern og nevrologiske fag. Den egner seg også godt for lesere med interesse for kriminalomsorg, barn og oppvekst, etikk, filosofi og nevrovitenskap.

Boken består av seks hoveddeler som er oversiktlig inndelt i kapitler. Kapitlene innledes med en oversiktsboks som oppsummerer hovedinnholdet i kapitlet, og de avsluttes likeledes. Kapitlene er kortfattede og gjennomgående godt skrevet i et lettfattelig språk - på tross av faglig kompleksitet. De seks hoveddelene heter Billeddiagnostikk, Hjernens nettverksfunksjoner og plastisitet, Klinisk nevropsykologi, Nevropsykiatriske tilstander, Nevropsykiatriske utviklingsforstyrrelser og Juridiske og etiske aspekter. Anbefalt litteratur og et selektert utvalg av referanser hjelper den interesserte leser til ytterligere fordypning.

Temautvalget er gjennomtenkt, og forfatterne har lang erfaring i feltet med blant annet aktiv deltakelse i Norsk forum for Nevropsykiatri, som har eksistert i over ti år. Jeg vil spesielt fremheve kapitlet om impulsivitet, svikt i impulskontroll og risiko for voldsatferd ved psykose og psykopati som et viktig oppdatert bidrag om et aktuelt tema.

Det har tradisjonelt sett vært lite kunnskap om etiologiske faktorer for psykiatriske tilstander. Nevrobiologisk kunnskap er i ferd med å endre dette bildet, og hjernens funksjon får en langt mer sentral plass i forståelsen av sykdomsutvikling og symptombilde. Dette vil forhåpentligvis også føre til mer spesifikke og målrettede behandlingsmetoder. Dessuten er det en optimisme ved hjernens plastisitet som vi ikke utnytter godt nok. Den amerikanske psykiateren Daniel Siegel har beskrevet dette på en god måte: «Where attention goes, neural firing goes. And where neurons fire, new connections can be made.»

Jeg synes boken er en god innføring i faget og kan trygt anbefale den til målgruppen og andre som er interessert.

Tone Skjerven

Klinikk for voksenpsykiatri

DPS Molde poliklinikk

Helse Møre og Romsdal

\section{En ubarmhjertig skjebne}

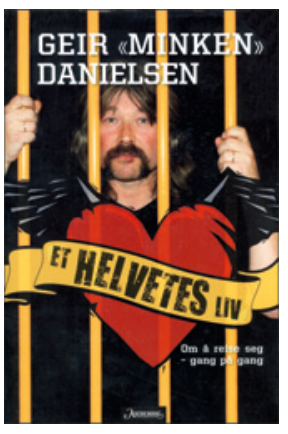

\section{Geir «Minken» Danielsen}

Et helvetes liv

Om å reise seg - gang på gang. 248 s, ill. Oslo: Aschehoug, 2011. Pris NOK 349

ISBN 978-82-03-29324-5

Forfatteren som nå er vel 50 år gammel, vokste opp i Grenland. Faren satt ofte fengslet for tyveri, og da han døde 48 år gammel, fikk sønnen en stefar som var både streng og voldelig. På skolen ble han mobbet av medelever og urettferdig behandlet av lærere på bakgrunn av farens fengselsopphold. Han ble lei av skolen og droppet ut av ungdomsskolen. Deretter begynte han i arbeid som jernbinder og sjauer på Rafsnes, og som skribent av bøker om jakt og fiske. Naturen ble hans store lidenskap, men han ble tidlig alkoholmisbruker.

Han giftet seg med en kvinne som støttet ham, og de fikk tre døtre. Tragedien rammet familien da en av døtrene omkom i en bilulykke, men det virkelig fatale skjedde en dag i desember 2005. På en hyttetur sammen med en bekjent kom det til krangel, og etter å ha blitt kraftig provosert av sin alkoholiserte «kamerat», trakk han frem pistolen som han hadde med for å skyte mink, og drepte kameraten.

Forfatteren soner i dag dommen. Først satt han fire år i Skien fengsel for så å bli overført til Berg fengsel ved Tønsberg. Det meste av manuskriptet til denne boken ble til under oppholdet i Skien fengsel.

Hva handler boken om? Om livet i fengselet og om hans tidligere liv i frihet, forholdet til kona og barna, hans fanatisk religiøse mormor som styrte alle i familien med jernhånd, onkler og andre. Vi får et innblikk i det han har opplevd på forskjellige arbeidssteder, og vi leser om hans voldsomme alkoholmisbruk. Vi hører om narkotikamiljøet i distriktet og innleggelser i psykiatriske avdelinger. Skien fengsel får sitt pass påskrevet. Langt mer menneskelige forhold opplever han på Berg.

Forfatteren har nok et hissig gemytt, men skal vi tro ham, er han preget av stor rettferdighetssans og omsorg for både kone og barn. En gang blir han uten grunn anklaget for å ha mishandlet døtrene sine. En annen gang blir han arrestert på arbeidsstedet, mistenkt for tyveri og med håndjern ført ut av arbeidslokalet der alle arbeidskameratene kunne bivåne det hele. Men politiet hadde tatt feil mann.

Dette er forfatterens debut som skjønnlitterær forfatter. Han skriver godt og interessant, og i motsetning til en del andre forfattere har han noe å fortelle. Språket er enkelt, men fargerikt og flyter godt av sted. Han bør absolutt skrive mer.

\section{Einar Kringlen}

Psykiatrisk institutt

Universitetet i Oslo 